\title{
Individual Ownership of Property in the People's Republic of China ${ }^{1}$
}

\author{
By Alison E.W. Conner
}

\section{Introduction}

The economic reforms implemented since 1978 in the People's Republic of China (the "PRC ( ) have not only allowed but positively encouraged individual citizens to become prosperous and thereby accumulate more property - "to get rich is glorious." At the same time, the General Principles of Civil $\mathrm{Law}^{2}$ and other recent laws provide greater legal protection to the individual's right to own (and inherit) that property, or to operate and use other property not subject to private ownership. It would seem that in its current views and practice the PRC now differs markedly from the Soviet Union - and from the Chinese past as well. The purpose of this paper is therefore to explore the scope of individual property rights in China as provided in its recently enacted civil law and other relevant legislation. Since the topic covers a broad area of rapid change, and practice has generally outpaced the law, this article can provide only a general picture of the current scheme. Perhaps even that may prove useful: the issues are of practical as well as academic interest, given the role material incentives now play in China's economic development.

\section{Soviet Legislation}

In Marxist theory, the ownership of property is the key to political as well as economic power: whoever owns the means of production (the most basic, productive forms of property), will necessarily control the state. In socialist states, therefore, ownership of property is the critical issue, and the fundamental principle of ownership is ordinarily that the means of production must be publicly rather than privately owned. That principle has not, however, been interpreted to require that all property be publicly owned, and socialist states do allow, to varying degrees, the ownership of property by individuals - the question is to what extent it will be permitted and on what theory.

1 This paper was originaly presented, in a somewhat different form, at the Symposium on General Principles of Civil Law of the PRC in Comparative Perspective, held March 25-29, 1988 in Hong Kong.

2 Adopted by the National People's Congress (hereafter called the "NPC«) on April 12, 1986, effective from January 1, 1987 (hereafter called the "Civil Law"). [1986] 12 State Council Gazette of the PRC 371 (May 20, 1986). An English translation by Whitmore Gray and Henry Ruiheng Zheng appears in "General Principles of Civil Law of the People's Republic of China, 34 American Journal of Comparative Law 729 (Fall 1986). 
In the Soviet Union, for example, theorists have long drawn a distinction between "private" property, meaning private capital used to make productive investments (which individuals should not be permitted to own), and "personal « property, referring to property intended to meet personal consumption needs (which individuals are permitted to own). ${ }^{3}$ That distinction is reflected in the current USSR Constitution, which provides for state or collective ownership of the means of production and for personal ownership of the means of livelihood. Thus, "(a)rticles of everyday use, personal consumption, convenience, and subsidiary household husbandry, a dwelling house, and labor savings may be in personal ownership «, and those items may also be inherited by individuals. ${ }^{4}$ The same article makes clear that the basis of personal ownership of citizens must be "labor income", and specifically provides that, in turn, such personal property »should not serve to derive non-labor income nor be used to the prejudice of the interests of society. ${ }^{5}$

The relevant Soviet civil law provisions on personal ownership, contained in the Civil Code of the Russian Soviet Federated Socialist Republic, ${ }^{6}$ are similar. The individual's right of ownership is limited to one dwelling house, ${ }^{7}$ and the 1983 RSFSR Housing Code provides further restrictions on the use, size, and disposition of such houses. ${ }^{8}$ More generally, black marketeers and speculators are controlled under parasite laws; private business (and the property used in them) have been severely restricted in size and scope, with numerous activities not permitted. ${ }^{9}$ The result is that in the Soviet Union the property an individual citizen may own has been strictly limited as to type and amount; although ownership of personal property, as narrowly defined, is permitted and protected, any individual ownership of the means of production (private property), or in general the use of personal property as a means of producing income, has been forbidden. ${ }^{10}$

\section{Individual Ownership under Past PRC Constitutions}

In China, as in the Soviet Union, the general legal framework relating to ownership may be found first of all in the state constitution; all four PRC constitutions (of 1954, 1975, 1978 and 1982) have contained provisions protecting individual ownership or property rights,

3 John N. Hazard, Communists and Their Law, (Chicago: The University of Chicago Press 1969), p. 202.

4 Article 13, translated in W. E. Butler, (comp., trans.), Basic Documents on the Soviet Legal System, (New York: Oceana Publications, Inc., 1983), pp. 6-7.

5 Ibid. The meaning of "non-labor income " has caused some practical and theoretical difficulties, but it has not been interpreted to exclude inheritance, gifts, lottery winnings, interest on savings accounts, and rental income within prescribed limits. W. E. Butler, Soviet Law, (London: Butterworths, 1983), p. 175.

6 Whitmore Gray and Raymond Stults, trans., Civil Code of the Russian Soviet Federated Socialist Republic, An English Translation, (Ann Arbor, Michigan: The University of Michigan Law School, 1965), pp. $28 \mathrm{ff}$.

7 Contained in Article 25; ibid.

8 Ibid., pp. 228-229.

9 E. L. Johnson, An Introduction to the Soviet Legal System, (London: Methuen \& Co Ltd, 1969), pp. 108, 110.

10 Despite the currently more liberal policies and some recent economic reforms relating to small urban and rural "cooperative" enterprises. International Herald Tribune, May 25, 1988, p. 1 and May 26, 1988, p. 1. 
although to different degrees. The first constitution, adopted in 1954, granted protection in Article 11 to the right of citizens to own "lawfully earned income, savings, houses and other means of livelihood," but also recognized private as well as public ownership of the means of production (Article 5). Thus, it specifically permitted the peasants to own land and other means of production (Article 8), and protected the right of individual workers and even capitalists to own capital and other means of production according to law (Articles 9 and 10). Those individual rights to property, however, were clearly limited and transitional: the expressed intention was to eliminate capitalist ownership and to guide individual workers and peasants on the path to cooperative forms of ownership.

The provisions of the next two constitutions, of 1975 and 1978, reflected the shift to public ownership. In both constitutions, capitalist owernship had completely disappeared, and although individual non-agricultural workers might still engage in individual labor as permitted by law, it could involve no exploitation; they also were to be guided into collectivization (Article 5). As before, individual citizens were still at least formally permitted ownership of "lawfully earned income, savings, houses, and other means of livelihood " Article 5); otherwise, commune members were allowed to farm small plots for personal needs, engage in limited household sideline production, and keep a limited number of livestock for personal use, but only within the "absolute predominance of the collective economy" (Article 7). In fact, all individual property rights were de-emphasized and it is clear that the role of economic incentives had a very limited role to play.

\section{Individual Ownership under the 1982 Constitution}

The fourth Constitution of the PRC ${ }^{11}$ was enacted after the economic reforms had begun, so that at least to some extent it reflects the current shift to more diverse forms of ownership. Of course, Article 6 of the Constitution still provides that the basis of the "socialist economic system" of the PRC is the "socialist public ownership of the means of production" (in the form of state or collective ownership), and Articles 9 and 10 require that land and natural resources, the most important means of production, be owned by the state or collectively owned. At the same time, however, individuals have been accorded greater rights than in 1975 or 1978 to own property in their capacity as citizens or individual workers. Thus, Article 13 now protects the right of citizens' ownership in their lawful income, savings, houses, and "other lawful property«, a broader formulation than in the three earlier constitutions, which referred only to "other means of livelihood. "Article 8 allows rural collective members to operate private plots and hillsides, engage in household sideline production, and raise privately owned liverstock, but without the limitations previously placed on that right. Finally, Article 11, as originally enacted, refers for the first time to the

11 Adopted by the NPC on December 4, 1982 (hereafter called the "Constitution"). Collection of Laws and Regulations of the PRC (hereafter the "Collection") (1982), (Beijing: Law Press, 1986), p. 1. 
"individual economy« (geti jingji) of urban and rural workers and provides for the protection of its lawful interests (with no formal requirement that it avoid exploitation); under an April 1988 amendment to that article an expanded "private economy" (siying jingji) has now also been given official recognition.

\section{Owernship under the Civil Law}

Although the PRC constitutions have provided the general legal framework, the detailed definitions and provisions on ownership and property rights in the PRC should ideally have been set out in a civil code, as in the Soviet Union. But the Civil Law was not adopted until 1986 and even then appeared in the form of "general rules" (tongze) rather than a comprehensive code, despite an early start to drafting in the 1950 's. ${ }^{12}$ There did, however, exist civil law textbooks systematically treating these issues, including one published in $1958,{ }^{13}$ as well as more recent, though pre-Civil Law, texts widely used in law schools. ${ }^{14}$

At present, the Civil Law does provide some further elaboration: Section 1 of Chapter 5 outlines both ownership of property (caichan suoyouquan) and certain property rights related to ownership (yucaichan suoyouquan youguande caichanquan). Article 71 defines ownership: it "means that the owner shall enjoy the rights of possession, use, benefit and disposition over his own property in accordance with law. " This general principle applies to all categories of owner (or "subjects « of ownership), including the state, collectives, and individual citizens, but the property they may own (the legitimate "objects " of their ownership), and the further restrictions placed on them by law, still differ. Thus, echoing the Constitution, Articles 73 and 74 provide that the major means of production (land and natural resources) must be publicly owned by the state or collectives.

What then are the possible objects of ownership for an individual, i.e., what types of property may the individual citizen own under the Civil Law? Article 75 has provided a somewhat more detailed answer than the Constitution:

A citizen's individual ${ }^{15}$ property includes the citizen's lawful income, house, savings, articles used in daily life, cultural objects, books and reference materials, trees, livestock and means of production that the law permits citizens to own, as well as other lawful property.

12 The fourth and final draft of a full code was widely circulated in 1982 (the "fourth draft civil code ").

13 Civil Law Teaching and Research Section, Central School for Political Cadres, Fundamental Problems of Civil Law of the PRC, (Beijing: Law Press, 1958).

14 For example, Tong Rou, et al, Principles of Civil Law (2d ed.), (Beijing: Law Press, 1985). The first edition appeared in 1983.

15 Transladed in Gray and Zheng, note 1 above, as "personal", the term used by the Soviets for such property. I have used the more literal "individual instead, since under the Chinese provisions property that could not be classified as "personal" in the Soviet legislation is included in Article 75. In any event, it might be argued that in the PRC, whatever the theories advanced, the practice has really gone beyond any such classification - and that even "private property" has been accepted. 
Most striking in this formulation (in contrast to the comparable Soviet provision, for example) is the explicit statement that the individual citizen in the PRC may own not only the means of livelihood but also certain means of production.

Article 75 does not distinguish between the ownership rights of an individual citizen and those of an individual worker, but civil law textbooks tend to analyze the individual's right to own property in terms of an individual citizen's ownership of the means of livelihood and the individual worker's ownership of the means of production. That approach undoubtedly results from the separate constitutional provisions, which in turn are based on the different justifications for permitting individual ownership of the two categories of property. At least some texts acknowledge, however, especially after the enactment of the Civil Law (and the clear language of Article 75), that the two forms of ownership are in fact combined in the individual citizen, ${ }^{16}$ and the two categories are now in practice increasingly being merged. But since the rationales for individual ownership in the two cases have remained separate, they will also be discussed separately below.

\section{Ownership by Individual Citizens: Means of Livelihood}

The subject of these ownership rights is the individual citizen, without regard to any distinctions, and the object is ordinarily the means of livelihood, that is, property that is used to satisfy the material and cultural livelihood needs of the citizen. ${ }^{17}$ Every citizen enjoys the right of ownership of the means of livelihood, since everyone requires them to support his existence; this is therefore the most common, most important type of property ownership for the individual. ${ }^{18}$ Property belonging to this category is held to be clearly socialist in character because (1) its source is the socialist public ownership system, (2) labor is the basic method of obtaining it, (3) the basic principle of obtaining the means of livelihood is "from each according to his ability, to each according to his work", and (4) consumption is the basic purpose of the citizen's owning such property. ${ }^{19}$

Article 75 of the Civil Law, as quoted above, has enumerated some types of property obviously includible as means of livelihood. ${ }^{20}$ Since each type of property presents somewhat different issues and may be subject to different restrictions under other legislation, they will be analyzed separately. Of course, as noted in the textbooks, the ownership rights to all

16 Hu Shixiang, et al, Lectures on the General Principles of Civil Law (Henan People's Press, 1986), p. 190.

17 Ibid., p. 191.

18 Civil Law Section, Chinese University of Politics and Law, Lectures on the General Principles of Civil Law of the $P R C$, (Beijing: Chinese University of Politics and Law Press, 1986), p. 133.

19 Tong Rou, note 14 above, pp. 182-84.

20 This sets out in somewhat more detail than the Soviet legislation what may be the object of individual ownership. But the Soviet approach is more restricted, and the real question is not the type of object or its natural properties, but its actual use: whether for personal consumption needs or for a profit. W. E. Butler, note 4 above, p. 172. In the Soviet Union, that would indicate whether the individual ownership of the item was permitted; in the PRC, however, although the same distinction might be drawn, it would be for the purpose of classifying the property (and therefore justifying its ownership), since an individual can own certain means of production. 
types of property are subject to general limits; they cannot be used to harm the public benefit (such as using property to engage in speculation, smuggling, profiteering, or bribery, nor can the relevant laws be violated (i.e., land cannot be bought or sold). ${ }^{21}$

\section{Lawful Income and Savings}

An individual citizen has first of all the right of ownership in his lawful income, as specified in both the Constitution and the Civil Law. It must be lawful, that is, derived from his own labor (either physical or intellectual) or from some other lawful method, and may take the form of money or payment in kind in any goods not prohibited by law. ${ }^{22}$ The most obvious examples of such income include wages and pensions but it may also include income from individual businesses, ${ }^{23}$ from agricultural cooperative members' sideline production or by such members contracting for land to engage in farming and producing grain, cotton, vegetables, and so forth, beyond the required contract amount or taxes due. ${ }^{24}$

Although one's own labor may be the most important means of obtaining lawful income (and its socialist character is partly derived from that), the PRC definition does not so restrict it; the only requirement is that it be lawful. Thus, the textbooks state that any other income lawfully obtained by citizens through various kinds of civil activities, for example through buying and selling, inheritance, gifts, ${ }^{25}$ and income from renting a house or from lending money, ${ }^{26}$ would also fall into this category. Those activities are permitted under related provisions of the Civil Law (or other legislation), and therefore money or property received from them is lawful income; since patent, trademark, copyright, and discovery rights are recognized in the Civil Law, any income obtained from them should qualify here too. Lawful income should also include insurance proceeds, now that insurance is becoming more common in China. But property obtained through illegal activities, for example through smuggling, speculation, or bribery, could not of course be considered lawful income within the meaning of Article 75.

Savings, defined as money deposited by citizens in banks or credit cooperative societies, constitute a related type of individual property, specifically listed in both the Constitution and the Civil Law, that may be the object of an individual's ownership rights. Such property is in fact encouraged, since it means that otherwise idle capital can be amassed and used for developing socialist construction, and at the same time it continues the people's tradition of being "hardworking and thrifty in managing their households. ${ }^{27}$

21 Qian Mingxing, Property Ownership Rights, (Beijing: Law Press, 1987, p. 8.

22 Tong Rou, note 14 above, p. 185; Zhou Yuanbo, ed., Explanation of the "General Principles of Civil Law" (Nanjing: Nanjing University Press, 1986), p. 92.

23 Qian Mingxing, note 21 above, p. 37.

24 Ibid, The definition was apparently limited to these items in the fourth draft civil code (Article 95), note 12 above.

25 Tong Rou, note 14 above, p. 185.

$26 \mathrm{Hu}$ Shixiang, note 16 above, p. 191. See the discussion relating to interest below.

27 Tong Rou, note 14 above, p. 185. 
More noteworthy is the fact that the interest on savings is also a protected form of property for the individual depositor. In PRC civil law theory, this follows from the right to benefit (shouyiquan), one of the constituent rights of ownership as defined in Article 71. The owner of the property is entitled to the benefit that derives from the property, or the "fruits " (zixi), which may be natural or legal; legal fruits (fading zixi), according to the textbooks, would include (but not be limited to) both rent payments for leasing out property and interest paid on savings. ${ }^{28}$ The practical justification is that paying interest is a legitimate way for the state to encourage citizens to save. Thus, although interest is clearly unearned income, it is said to have no exploitative character and it therefore receives the same protection as other lawful property. ${ }^{29}$

\section{Houses (or Apartments)}

Although land must be publicly owned, houses and other buildings (even if seen as unique than fungible property and classified by some as "immovables $\ll)^{30}$ are viewed as separate property that may be the object of individual ownership. Indeed, houses have been viewed as the most important of the means of livelihood; protection of ownership by individual citizens of their houses has consistently been stated in PRC constitutions (though not always obtaining in practice). This type of individual property has in the past been more common in the countryside, since rural collective members generally own their houses (and they increasingly have the means to build them). ${ }^{31}$ The peasants cannot, however, own their house sites; Article 6 of the Land Management Law of the PRC ${ }^{32}$ specifically provides that they remain the property of the collective. ${ }^{33}$

Some city dwellers also own their homes, especially since many private houses confiscated during the Cultural Revolution have now been restored to their owners. In urban areas, however, individual ownership is subject to certain legislative restrictions, the 1983 Regulations on the Administration of Private Urban Houses, ${ }^{34}$ for example, contain provisions on the ownership, registration, sale and purchase, and leasing. Those regulations clearly treat private houses as means of livelihood (and scarce ones given the severe housing

28 Zhou Yuanbo, note 22 above, pp. 86-87. Hu Shixiang, note 16 above, p. 191, gives the same examples as "legal fruits." But that reasoning was unequivocally rejected by the authors of the 1958 Fundamental Problems of Civil Law of the $P R C$, note 13 above, p. 118.

29 Ibid.

30 Civil Law Teaching and Research Section of the Southwest Political-Legal Institute, Application of Our Country's Policy and Law Relating to Housing Property, (Chongqing, 1984), pp. 24-25.

31 Zhou Yuanbo, note 22 above, p. 92.

32 Adopted by the NPC Standing Committee on June 25, 1986. [1986] 17 State Council Gazette of the PRC 531 (July 10, 1986).

33 A right to use the house site (zhaijidi shiyongquan) might have been provided in the Civil Law, along with the other property rights related to ownership contained in Section 1 of Chapter 5, but in the end was not included. See disscusion below.

34 Issued by the State Council on December 17, 1983. Collection (1983), Beijing: Law Press, 1986), p. 345. 
shortage in cities). But recent changes in official housing policy will greatly affect individual ownership of houses in the cities. In the last few years individuals have increasingly been encouraged to purchase their houses or flats, instead of paying nominal and heavily subsidized rent for housing owned by the state or work units, and various schemes have been proposed to allow them to finance the purchase. ${ }^{35}$ Houses and other buildings would then be treated as commodities, with a developed real estate market. ${ }^{36}$

\section{Articles Used in Daily Life; Cultural Objects and Books}

This category includes the personal property that would be most commonly owned in the PRC: individual and family members' foodstuffs, clothing, furniture, daily household articles, bicycles, electrical goods, and so forth, ${ }^{37}$ all articles intended for personal consumption and therefore most obviously classified as means of livelihood. Cultural objects (wenwu) refer to objects with special historical, artistic, or scientific value, including such things as precious artistic items, old paintings and books with historical or artistic value, ancient buildings, monuments and inscriptions, and even revolutionary memorabilia (few individuals would own such property now).$^{38}$ Although their ownership by individual citizens is specifically protected, because of the special character of such objects the individual owners must abide by relevant regulations, in particular the Law of the PRC on the Protection of Monuments and Cultural Objects. ${ }^{39}$

\section{Trees and Livestock}

Trees and livestock could be classified as either means of livelihood or means of production, depending on their use. The Constitution specifically permits the raising of privately owned livestock, and according to the texts that includes all kinds. ${ }^{40}$ Since forests as well as other natural resources can only be publicly owned, trees grown in forests, even if cultivated by individuals, cannot become their individual property. But the Forestry Law of the PRC (For Trial Implementation) ${ }^{41}$ provides that trees planted by people's commune members around their houses or in places designated by the production teams shall be owned by

35 Such sales began on an experimental basis in some cities in 1982, and in Beijing began in 1985. "Beijing to begin selling apartments to residents", China Daily, December 31, 1984.

36 See the "Implementing Plan Concerning the Implementation of the Housing System Reform by State in the whole Country“, Legal System Daily, March 10, 1988.

37 Qian Mingxing, note 21 above, p. 38.

38 The Soviet Union has a similar statute. W. E. Butler, note 4 above, p. 175.

39 Article 5. Adopted by the NPC Standing Committee on November 19, 1982, in Collection (1982), (Beijing: Law Press, 1986), p. 565.

40 Qian Mingxing, note 21 above, p. 39.

41 Adopted in principle by the NPC on February 23, 1979; Collection (1979), (Beijing: Law Press, 1986), p. 221. See Article 3. 
the individual members. The Constitution also permits rural collective members to operate private plots and hillsides. Therefore the most important examples of this category include the trees on peasants' house sites and on their private plots and hillsides, as well as trees grown on land they cultivate according to contract. ${ }^{42} \mathrm{With}$ both types of property-livestock and trees-their "natural fruits" (tianran zixi) may also belong to the peasants owning the original property (yuanwu). ${ }^{43}$

\section{Other Lawful Property}

Although many types of individual property are specifically enumerated in article 75 , that article also contains the open-ended »other lawful property «, presumably intended to cover any items on which agreement has yet to be reached, as well as new property developed in the future. Few textbooks suggest what might be included, saying only that the possible types of property were too extensive to list. ${ }^{44}$ It appears, however, that stocks and bonds, as well as other intangible property, should fall into this category. ${ }^{45}$ Intellectual property rights, four of which are recognized in Section 3, Chapter 5 of the Civil Law, should also be included; thus, individual citizens may enjoy patent, trademark, authorship, and discovery rights, under Articles 94 through 97 of the Civil Law. ${ }^{46}$ According to the textbook writers, the content of such intellectual property rights includes both personal rights (which cannot be separated from the person) and property rights (such as the right of publication), which can be separated from the individual creator and therefore may be transferred or inherited. ${ }^{47}$

42 Zhou Yuanbo, note 22 above, pp. 92-93.

43 Ibid., p. 86. For example, eggs laid by hens, and fruit from fruit trees.

44 Qian Mingxing, note 21 above, p. 39.

45 Certainly suggested by a n opinion of the Supreme People's Court issued on September 11, 1985, which indicates that stocks would be included in heritable property. Despite some local regulations and experiments with local stock markets, stocks and bonds have so far been issued on a very limited basis in the PRC. In March 1987 the State Council issued a notice prohibiting state enterprises from issuing stock to the general public, indicating that issuing stock is mainly collective enterprises. Interim regulations were also promulgated to govern the issuance of bonds by stateowned enterprises. The debate on stocks and bonds is a continuing one, however.

46 The PRC has already enacted some relevant national legislation, including the Trademark Law of the PRC, adopted by the NPC Standing Committee on August 23, 1982, in Collection (1982), (Beijing: Law Press, 1986), p. 519; the Patent Law of the PRC, adopted by the NPC Standing Committee on March 12, 1984, in Collection (1984), (Beijing: Law Press, 1986, p. 529; and the Law of the PRC on Technology Contracts, adopted by the NPC Standing Committee on June 23, 1987, in [1987] 15 State Council Gazette of the PRC 515 (June 26, 1987). No copyright law has yet been enacted in the PRC, although a draft is currently in preparation and various "internal" regulations relating to authorship rights or royalty payments have been adopted in the past.

47 Liu Chuntien, Intellectual Property Rights, (Beijing: Law Press, 1986), pp. 2-3. 


\section{Ownership by Individual Workers: Means of Production}

If it were not already clear that the PRC has departed from the Soviet view on the proper scope of individual property, it would now become so, for in the PRC it is possible for at least some of the means of production (as well as the means of livelihood) to be in private hands. The Constitution protects both the citizen's "other lawful property" and the individual economy of urban and rural workers, thereby providing the basis for individual ownership of some productive materials and tools for those workers. In addition, Article 75 of the Civil Law specifically cites the "means of production which may be owned by citizens within the limits of the law « as part of a citizen's individual property.

According to civil law textbooks, the subjects of this ownership right are urban or rural workers permitted by law to engage in individual operations,,$^{48}$ and at least at the beginning that meant workers (or households) engaged in commerce, small-scale handicrafts, food and beverages, service trades, repair work, transport, and house repairs, although this has now been somewhat expanded by later regulations. ${ }^{49}$ The object of such ownership (or the scope of the property individuals could own) was therefore generally small-scale production tools, i.e., hand tools, instruments, materials for repair work, or equipment needed for food stalls. As a result of their successful operations and increasing prosperity, however, their property has come to include, at the least, machine tools, large tractors, motor vehicles, boats, and other medium-scale means of production. ${ }^{50}$

The practical reasons for permitting the individual ownership of such means of production (as distinguished from the means of livelihood) in individual business are obvious: they supply needed employment and services the public economy cannot provide itself. But what is the ideological justification? According to the civil law textbooks, the individual workers or households were orginally individuals not participating in state or collective economic organs (i.e., the unemployed), who used small-scale production tools or a small amout of capital, in addition to their own labor, to engage in productive activities that did not exploit others. Such activities cannot, it is argued, be considered the same as those in the private economies of capitalist countries, because in the PRC they only supplement the public economy and are subject to its leadership, administrative regulation, and supervision. In addition, individual enterprise accords with the goal of increasing production and thus is

48 Arguably, the subjects must be the individual citizens and not the individual enterprises. Although individual enterprises are recognized and defined in Article 26 of the Civil Law, they are not separate legal entities that might also be the subject of property rights. At least for purposes of this analysis, it would seem that the individual citizens or their families own such means of production as their individual property.

49 Those are the trades listed in Article 1 of Certain Policy Provisions Relating to the Non-Agricultural Individual Economy in Cities and Townships, issued by the State Council in July 7, 1981; Collection (1981), (Beijing: Law Press, 1986). The latest regulations are the Provisional Regulations on the Administration of Urban and Rural Individual Industrial and Commercial Households, issued by the Council on August 5, 1987; [1987] 20 State Council Gazette of the PRC 670 (August 31, 1987). But those regulations, like their predecessors, place no direct restrictions on the type or amount of property that may be owned and used in these trades.

50 Tong Rou, note 14 above, pp. 180-181; Zhou Yuanbo, note 22 above, p. 93; Chinese University of Politics and Law, note 18 above, p. 134. 
used to develop and encourage the socialist system. ${ }^{51}$ In other words, such ownership is socialist because it is non-exploitative in character, because it serves socialist goals, and because it is simply a supplement to the dominant socialist public economy..$^{52}$

\section{The Development of the Private Economy}

That development has now been taken at least one step further, with the encouragement of the private economy. The private enterprise, usually defined as one employing at least eight outside workers, ${ }^{53}$ first appeared in 1981, developing naturally out of the more successful and expansive individual enterprises and households. Although such enterprises were permitted to develop over the last seven or eight years (according to recent reports they now number at least 225,000 , employing more than 3.6 million workers), ${ }^{54}$ they were subject to no formal legal regulation. The private economy received positive recognition, however, in the report delivered by Zhao Ziyang at the Communist Party's 13th National Congress, held in October 1987. At the same time he affirmed the predominance of public ownership, the general secretary stressed the development of diverse sectors of the economy: "cooperative, individual, and private sectors of the economy in both urban and rural areas should all be encouraged to expand. ${ }^{55}$ Amid a flurry of positive articles in the press about private enterprises, the National People's Congress on April 12, 1988 amended Article 11 of the Constitution to add a clause protecting the private economy, ${ }^{56}$ and in June 1988 the long-awaited (and more detailed) regulations on private enterprises were promulgated. ${ }^{57}$

Those private enterprise regulations contain further assurances on the protection given to investors' ownership rights in private enterprise property and permit them to operate in the same broad range of industries and trades as the individual enterprises (scientific and

51 Tong Rou, note 14 above, pp. 180-81; Hu Shixiang, note 16 above, p. 193.

52 It is true that individual enterprises still constitutes a small percentage of the overall economy in the PRC; of the total industrial output value, the individual economy accounts for only $3 \%$, whereas the public sector accounts for $80 \%$, and the collective and cooperative sectors $15 \%$. "Policy encourages individual sector", China Daily, December 15,1987 . In fact, however, individual enterprises plays a much greater role than those figures would indicate; thus, it accounts for $87 \%$ of all repair services, and employed a total of 18.8 million people by the first half of 1987. Ellen Salem, "Pedding the private road", Far Eastern Economic Review, October 8, 1987, p. 106. The official figures usually cited in the PRC press are: 13.7 million total private and individual enterprises, employing 21.5 million workers. People's Daily (overseas ed.), April 13, 1988. And a recent report indicated that retail sales came to nearly 75 million yuan, accounting for $13.7 \%$ of the country's total. China Daily, September 14, 1988.

53 Under the regulations cited in note 52 above, individual enterprises are limited to no more than two "assistants" and five sapprentices, " for a total of seven employees - although the regulations carefully avoided using that term.

54 Some reports give the figures as 115,000, with 1.8 million employees. People's Daily (overseas ed.), March 16, 1988. The larger figure apparently includes some private enterprises registered in affiliation with local collectives. China Daily, June 25, 1988.

55 English translation appearing in Bei jing Review, November 9-15, 1987, pp. I-XXVII.

56 People's Daily (overseas ed.), April 13, 1988, p. 1.

57 Provisional Regulations of the PRC Concerning Private Enterprises, promulgated by the State Council on June 25, 1988; People's Daily (overseas ed.), June 30, 1988. 
technological consultancy has also been added to the list). It is true that under the regulations private enterprises may not engage in military or financial industries, nor do business in commodities prohibited to them by the state, ${ }^{58}$ but they otherwise have a free hand. By definition, of course, private enterprises, unlike individual enterprises, are not limited as to the number of workers they may employ. The justification for allowing such enterprises is similar to that for individual enterprises, although the argument is somewhat harder to make, given their size and larger workforce. Individual enterprises were seen, at least in the beginning, as small-scale operations with only a few employees: exploitation of workers was viewed as the critical element and therefore the number of such workers was limited, not the amont of property. But some private enterprises now operate on a vast scale bearing little resemblance to the small one-person operations originally, recognized in Article 11 of the Constitution. ${ }^{59}$

What this means is that right to own and operate large-scale means of production has been given, at least indirectly, constitutional blessing, and recent legislation has placed few limits on an individual's permissible property in either individual or private enterprises. Of course, the Constitution and other laws discussed above place certain restrictions on the ownership of land and natural resources, but there seem to be few other meaningful restrictions on the individual ownership of the means of production in the PRC today (and even some productive rights approaching ownership in those).

\section{Property Rights Related to Ownership}

Section 1, Chapter 5 of the Civil Law contains other important property rights related to ownership, in addition to the ownership rights themselves. According to the textbook writers, five such rights are provided therein, ${ }^{60}$ two of them conferring on the individual certain rights in state or collective property. ${ }^{61}$ Thus, even though the ownership of such prop-

58 Including cultural objects, jewelry, rare minerals, firearms and ammunition, cars and civilian explosives. People's Daily (overseas ed.), June 30, 1988.

59 For example, an interview with Zhang Guoxi of Jiangxi, possibly the richest of the private entrepreneurs, revealed that he owns "thirty-two factories, seven commercial companies and a network of cottage industries", in which he employs some 2,000 workers. South China Morning Post, May 14, 1988. Or Liu Xigui from Shenyang, whose private transport business has forty-nine motor vehicles, 240 employees and fixed assets worth 5.2 million yuan. Mr. Liu has recently figured prominently in the news because of his application to join his local branch of the Chinese Communist Party; although the application has aroused a great deal of controversy in thee PRC, it has not been rejected out of hand. South China Morning Post, August 26, 1988; China Daily, September 9, 1988.

60 Discussed in Hu Shixiang, note 16 above, pp. 197-203; Chinese University of Politics and Law, note 18 above, pp. 140-145. The other three are (1) the right to use and benefit from (yongyiquan) state lands and natural resources (Article 80 and Article 81(2) ); (2) the right of a state-owned enterprises to operate state property (jingyingquan (Article 82); and (3) mneighbourhood relationship" rights (xianglingquan) (Article 83).

61 A third potential right for individuals, to the use a house site (zhaijidi shiyongquan) in the countryside, does not appear in the Civil Law, although the right is undoubtedley protected. Because of the different circumstances regarding site use in different areas - and particularly the illegal occupation of land in some places - the Civil Law contains no provisions on such rights in order to a void recognizing such illegal occupation. Chinese University of Politics and Law, note 18 above, pp. 144-145. 
erty cannot lawfully be transferred to him, the individual citizen may have the right (1) to operate under contract collectively owned or used land and forests and other resources (chengbao jingyingquan), ${ }^{62}$ and (2) to exploit certain state-owned mineral resources (caikuangquan). ${ }^{63}$

The right to operate under contract is of two types, depending on the object (either land or forests and other resources); but the basic principles are the same in both cases. The content of the chengbao right, that is, the rights and duties of the parties, are derived from the contract. The contracting individual obtains the right to occupy, to use and to obtain the benefits from the use of the property (after payment of agricultural tax and the contract amount to the collective); in return he must manage and protect the property, and return it at the end of the contract. He clearly lacks complete ownership rights, for he may not sell, lease, mortgage or in any other way illegally transfer the land or resources. ${ }^{64}$ This arrangemant in some respects resembles a right of usufruct in land, ${ }^{65}$ but it grants no rights in the land itself (only the right to use it under contract).

The individual citizen may also be the subject of the right to exploit state-owned mineral resources under Article 81(2) of the Civil law. ${ }^{66}$ According to the Mineral Resources Law of the PRC, ${ }^{67}$ lawful mining by individuals must be supervised, guided and helped by the state administration. The content of the right to extract mineral resources is that the individual citizen has the right according to law to mine and extract the state mineral resources, to obtain mining income according to law, and to prevent others from illegally interfering with his right to mine, once he has received approval ${ }^{68}$ But the individual may not assign his mining right, lease it, or pledge it as security. ${ }^{69}$ Since mineral resources, the object of that right, are depleted through mining, the state must receive compensation for the right to mine; the state has the right to receive certain natural resource fees, prospecting fees, and management fees (it may also prevent miners from amining activities of destructive or despoiling nature). ${ }^{70}$

62 Article 80(2) and 81(3).

63 Article 81(2).

64 Hu Shixiang, note 16 above, p. 201; Chinese University of Politics and Law, note 18 above, pp. 142-143.

65 And some writers have described it as a type of usuf ruct. See Ye Lin, The Right to Operate under Contract, (Beijing: Law Press, 1987), p. 4.

66 At least one text has made clear this type of mining right is not the same as usuf ruct; Hu Shixiang, note 16 above, p. 199. But then what is it? One writer has argued that it is essentially a transfer of ownership of the minerals removed from the state to the person mining - despite the PRC position that the ownership of mineral resources cannot be transferred. See Eduard J. Epstein, "The Theoretical System of Property Rights in China's General Principles of Civil Law," conference paper.

67 Adopted by the NPC Standing Committee on March 19, 1986; [1986] 8 State Council Gazette of the PRC 195 (April 10, 1986).

68 Ibid

69 Ibid., Article 3.

70 Hu Shixiang, note 16 above, p. 199. 


\section{Land-use Rights}

In the two cases described above, the rights granted to individuals are not sufficient to constitute legal ownership, although they are nevertheless substantial rights in property. But both rights are surpassed by the "land-use rights " (tudi shiyongquan) now being granted in some cities and special zones in the PRC. Under recent legislation in Shanghai, for example, it is possible to acquire the right to use land for specified purposes for terms of up to fifty years, in return for compensation paid to the state. As a general matter, the land-use rights are transferable, and may be sold, assigned, pledged, and even inherited during the term granted (the term is also subject to renewal). ${ }^{71}$ Fuzhou, Shenzhen and Hainan have also issued their own regulations governing the transfer of such land-use rights for periods ranging from fifty to ninety years.

The Shanghai measures reiterate the principle that legal ownership of the land must remain with the state, and PRC commentators emphasize that it is only the right to use land for specified purposes that is sold. But the rights granted do in some respects approach economic ownership of the land, and that is recongnized in outside press reports refering to "sales" of urban land; even the method of offering the rights, by auction or public tender, is reminiscent of actual land sales. Most such legislation, enacted in special economic zones or cities as part of the open policy, is of course aimed at foreign and Overseas Chinese investors, rather than ordinary citizens of the PRC. But the Shanghai and other local regulations do not exclude PRC citizens from obtaining such rights (even if most lack the necessary financial resources); and individual citizens might also receive such rights through inheritance or other transfer.

When the initial regulations were enacted, and even when the first auctions of such land-use rights took place, the Constitution made no provision for such transfers. But a second important constitutional amendment adopted by the NPC in April 1988 deleted the word »lease« (chuzu) from Article 10(4). The amended article now reads "No organizations or individuals may appropriate, buy or sell land, or unlawfully transfer land in other ways. The right of land use can be transferred in "accordance with the law. "Such broad transfers of urban land have thus been given constitutional legitimacy, which can only encourage a much wider use of such transfers.

\section{Conclusion}

This paper has examined the scope of property that an individual citizen clearly enjoys extensive rights in property, seemingly far beyond those permitted to the Soviet citizen. Thus

71 See Shanghai Municipality Measures on the Compensatory Transfer of Land-Use Rights, issued by the Shanghai Municipal People's Government on November 29, 1987, China Laws for Foreign Traders and Businessmen (Special Zones and Cities) P91-034. Hainan Land Management Measures, published in Wen Hui Po, February $25,1988$. 
he may own not only any of the means of livelihood (which may even include unearned income), but also many types of property that must be classified as the means of production. In addition, the individual may acquire substantial rights in the means of production that can only be publicly owned, land and natural resources. In all cases, the property he owns, and in some cases, even the related property rights, may also be inherited. ${ }^{72}$

That such rights must still be analyzed within the framework of socialist ideology is significant, but the task of justifying individual ownership of property has become immeasurably easier since the »primary stage of socialism concept was introduced. If most forms of property may now be owned by individuals, the means of livelihood/means of production dichotomy may no longer have much force, despite its survival in the textbooks. Of course, the continued emphasis on ideology leaves open the possibility of reinterpretation and a consequent shrinking of property rights, as in the past; at the moment, however, few practical restrictions remain and all indications point to further expansion. If the intention is to provide individuals with greater material incentives for increased production, then these should serve.

72 Under the Inheritance Law of the PRC, adopted by the NPC on April 10, 1985. In Collection (1985), (Beijing: Law Press, 1986), p. 1. 


\title{
ABSTRACTS
}

\section{Human Rights and the Changing Concept of State and International Community}

\author{
By Otto Kimminich
}

Even those authors who go back to ancient Greece to explore the origins of the idea of human rights admit that this idea entered the world of political thought only after the concept of the modern State had taken shape. From the beginning it appeared to be a counter-movement. This has remained the fundamental problem of human rights on the international level: on the other hand their implementation is entrusted to a legal system whose constituting entities are sovereign States.

The problem can be solved if the position of the individual in international law is re-considered. This has been done theoretically, but State practice is slow to follow. One of the areas in which developments have been under way for decades is international refugee law. Another one is the right of peoples and ethnic groups to self-determination. But apart from such exceptions individuals and groups of individuals do not surface on the international level as holders of inherent rights. When international law testifies to these rights it still considers the individual to be a mere beneficiary.

This unsatisfactory state of development is dangerous in view of the fact that violations of human rights are increasing world-wide. They are not simply the result of extreme situations in isolated States. Rather it seems that modern government, steadily increasing its sphere of influence and power, threatens the scope of individual freedom everywhere. At the same time, however, the system of nation States has entered into an era of profound transformation. Huge and far-reaching migrations are beginning to create mixed populations of multinational and multicultural States. Transnational ties and regional cooperation are cracking the shell of the encrusted nation State. In this difficult situation the interrelationship between peace and human rights becomes more evident than ever.

\section{Individual Ownership of Property in the People's Republic of China}

\author{
By Alison E.W. Conner
}

Under the PRC's Constitution and its General Principles of Civil Law, the ownership system in China is divided into at least three categories, including state, collective and individual ownership. Within this scheme, the property that may be owned depends on the category of owner; as in other socialist countries, the most important means of production are 
to be owned publicly, either by the state (the "whole people«) or by collective organizations. Both the Constitution and the Civil Law, however, specifically permit ownership of certain property by individual citizens. The purpose of this paper is to explore the scope of a citizen's individual ownership, as provided in the Civil Law and other recent legislation enacted as part of the PRC's economic reforms.

Two main questions are considered: (1) what types of property may an individual own and (2) what other property rights related to ownership may an individual have. The conclusion is that in the PRC an individual may have ownership rights in a wide range of property, including those classified as means of livelihood and means of production; and he may obtain extensive rights related to property in other means of production, land and natural resources. The current position represents a marked change from past views in the PRC and also from the law of some other socialist countries.

\section{Preservation of Public Security Through Executive Restraint of Personal Liberty: A Case Study of the Kenyan Position}

\section{By Albert O. Mumma}

The paper argues two points. One that the provisions that empower the executive to administratively detain persons without trial in Kenya lack constitutional validity. Two that whatever safeguards are in place for the supervision of the exercise of these powers with a view to the protection of the rights of the detained person have proved ineffective.

The view is advanced that the validity of constitutional powers is a matter to be determined objectively rather than subjectively. This requires that their exercise conform to objectively determinable criteria. In the area of individual rights and freedoms these criteria are to be found in the state's obligations under the relevant international conventions and also in the objective circumstances obtaining in the country in question at the time of the exercise of these powers. Therefore, the bare assertion by the executive that an emergency situation exists severe enough to necessitate its resort to detention powers will not suffice. Under these criteria the situation in Kenya does not warrant resort to detention powers.

It is normal to enshrine saf eguards against the arbitrary exercise of detention powers. In Kenya these saf eguards have not worked to protect the detained person. In fact the ultimate safeguard, the courts, have themselves contributed to this failure by invariably interpreting any doubt in the law against the liberty of the subject. The paper concludes by pointing out that the combination of invalid emergency powers and ineffective safeguards against their arbitrary exercise poses a threat to the rule of law in the country. 